This item was submitted to Loughborough's Research Repository by the author.

Items in Figshare are protected by copyright, with all rights reserved, unless otherwise indicated.

\title{
External urban relational process: introducing Central Flow Theory to complement Central Place Theory
}

PLEASE CITE THE PUBLISHED VERSION

https://doi.org/10.1177/0042098010377367

PUBLISHER

Sage (@ Urban Studies Journal Limited)

VERSION

AM (Accepted Manuscript)

LICENCE

CC BY-NC-ND 4.0

\section{REPOSITORY RECORD}

Taylor, Peter J., Michael Hoyler, and Raf Verbruggen. 2019. "External Urban Relational Process: Introducing Central Flow Theory to Complement Central Place Theory”. figshare. https://hdl.handle.net/2134/7416. 
This item was submitted to Loughborough's Institutional Repository (https://dspace.lboro.ac.uk/) by the author and is made available under the following Creative Commons Licence conditions.

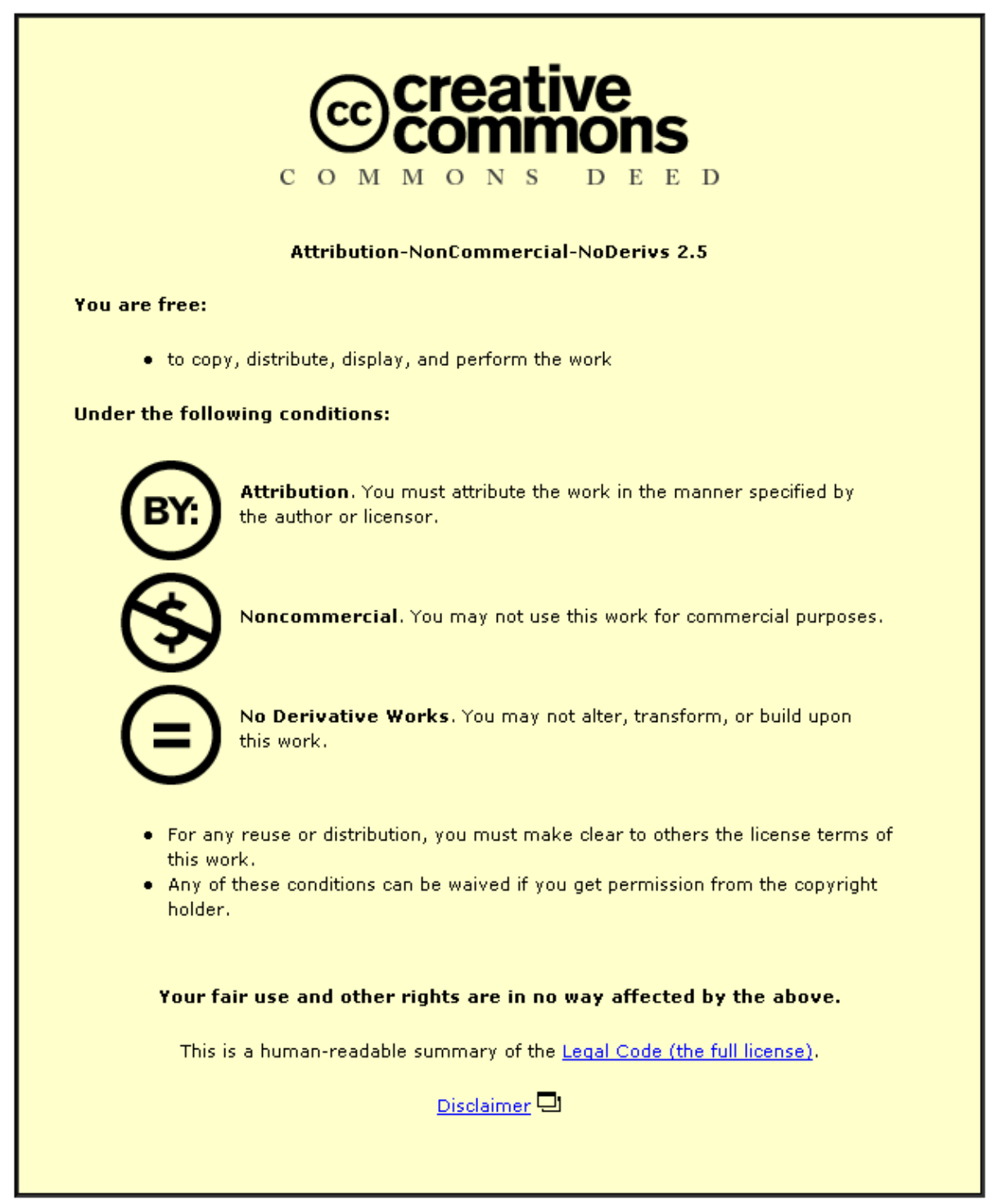

For the full text of this licence, please go to: http://creativecommons.org/licenses/by-nc-nd/2.5/ 


\title{
External Urban Relational Process: Introducing Central Flow Theory to Complement Central Place Theory
}

\author{
Peter J. Taylor*, Michael Hoyler** and Raf Verbruggen ${ }^{\star *}$ \\ * School of the Built and Natural Environment, Northumbria \\ University, Newcastle upon Tyne, NEI 8ST, UK \\ E-mail: crogfam@yahoo.com \\ ** Department of Geography, Loughborough University, \\ Loughborough, LE11 3TU, UK \\ E-mail:m.hoyler@lboro.ac.uk and r.verbruggen@lboro.ac.uk
}

\begin{abstract}
Central place hierarchies have been the traditional basis for understanding external urban relations. However, in contemporary studies of these relations, a new emphasis on urban networks has emerged. Rather than either abandoning or extending central place thinking, it is here treated as representing one of two generic processes of external urban relations. Town-ness is the making of 'local' urban-hinterland relations and 'city-ness' is the making of 'nonlocal' inter-urban relations. Central place theory describes the former through an interlocking hierarchical model; this paper proposes a central flow theory to describe the latter through an interlocking network model. The key difference is the level of complexity in the two processes.
\end{abstract}




\section{Introduction}

The purpose of this paper is to provide a rethinking of how we study the external relations between urban places. Traditionally, conceptualisation of these relations has been satisfied by central place theory with its depiction of a spatial-hierarchical arrangement of settlements. However this theory has had a curious recent history within contemporary urban scholarship. On the one hand its formal spatial modelling has become unfashionable in Geography so that it has all but disappeared from urban geography research agendas. ${ }^{1}$ It has appeared in the revival of geographical economics but only for its deficiencies to be emphasized. ${ }^{2}$ Nobody, it seems, has a good word to say about the theory. On the other hand, however, the influence of a theory is not to be measured purely in terms of its overt applications. There can be a much more subtle effect of theory through its ideas passing into the unexamined assumptions of its field of study. This is what we think has happened in on-going research on the external relations of urban places. We would argue that 'central place thinking' is represented in the 'new economic geography/geographical economics' through the ubiquitous assumption that towns and cities are ordered in hierarchies. The 'rethinking' that we engage in here is to argue that hierarchical relations between urban places constitute only a partial understanding of inter-city relations. As well as the 'vertical' relations emanating out of 'central place thinking', it is necessary to treat distinctive and separate 'horizontal' relations that define city networks.

The new economic studies of cities have been very unbalanced endeavours: great strides have been made in understanding intra- 
urban processes while researching inter-urban processes appears to have taken a back seat. For instance, Jane Jacobs' (1969) ideas of endogenous city growth have contributed to agglomeration theory (Glaeser et al., 1992), but her insistence that 'cities need each other' has been conspicuous by its absence in economic studies. Jacobs is one of the few classical urban theorists who do not assume inter-city relations are only hierarchical; thus she is deemed to be irrelevant for economic treatment of urban external relations. We will attempt to correct both the specific disregard of Jacobs and the general neglect of inter-city studies in this paper. But in doing so we move away from the unhelpful urban economics literature to other sections of urban studies where city networks have featured prominently: in multi-nodal city planning studies, early modern historical studies, and the global/world city literature. Selected parts of all three of these areas of scholarship have highlighted the need to understand city networks which we draw upon and develop using Jacobs' (1969) nonhierarchical treatment of cities. We set the argument into the organizational framework of Powell (1990) and Thompson (2003) who teach us of the importance of distinguishing between market, hierarchy and network as separate social processes.

Although covering similar ground to authors who argue that central place theory is inadequate for understanding contemporary urban external relations, we differ in not wishing to dispatch central place theory to the dustbin of history. Meijers (2007), for instance, identifies a "paradigm change" with the "network model" superseding central place theory; they are described as being "essentially opposite" to each other (p. 246). ${ }^{3}$ Drawing on the work of Camagni and Salone (1993), Batten (1995), Davies (1998) and van der Knaap (1992), Meijers (2007) describes an intellectual "transition" (p. 248) in 
conceptualizing urban external relations, which is deemed strong enough to warrant Kuhn's scientific appellation of "paradigm shift" ( $p$. 257). Be that as it may, the basic processes identified in central place theory continue unabated whether or not social scientists choose to study them: there is a spatial patterning to consumer society that continues to be concentrated in central places (Dale and Sjøholt, 2007). We interpret central place theory as describing a generic urban process, one of relations between an urban place and its hinterland. Thus we have no interest in jettisoning central place theory. However, the consensus that current urban external relations require more than this one theory (e.g. Parr, 2002) has led us to identify a different external urban process that can be theorised to produce a complementary set of conceptual tools. As well as the hierarchical structure postulated by central place theory, we argue that there is a network structure between cities. Whereas the former is a vertical spatial structure linking local scales of interactions (hinterlands), the latter is primarily a horizontal spatial structure linking non-local interactions. We treat both as generic urban processes and therefore both are required to adequately describe external urban relations now and in the past.

There is, of course, nothing new in understanding that cities have relations with other cities beyond their hinterlands and that this is an important process: this is the basis of the traditional research field of macro transport geography, especially port geography. What we offer here is a more formal approach to such interactions that we set alongside central place theory: the latter is modelled as interlocking hierarchies, we introduce a central flow theory modelled as interlocking networks. Clearly this differentiation of external urban relations into two theories draws upon Castells' (1996/2001) classic 
identification of two distinct social spaces: spaces of places and spaces of flows. Following Arrighi (1994) in eschewing Castells' particular use of the terms just for characterizing his interpretation of contemporary society, we argue that both social spaces exist in all societies and that they need to be understood in tandem (Taylor, 2007a). This is what we attempt below for external urban relations.

The paper consists of three substantive sections. First, we develop the argument for the need for a second external urban relations theory by focusing on debates concerning hierarchy and scale. Second, we provide a basic restatement of central place theory as describing generic urban local relations. Third, central flow theory is introduced as describing generic urban non-local relations.

\section{On the Need for a Second Theory of External Urban Process}

Central place theory has been developed in two directions: settlement geography and retail geography; in the latter, this includes intra-urban relations. Here, we focus on limitations of the former as a means of understanding the spacing and hierarchy of towns and cities. A common criticism of the theory that we set aside straightaway is dislike of its normative nature. Berry (1967, p. vii) treats the theory as a 'deductive base' through which to explore urban settlement patterns and we use it in this manner here: without fixation on the formal theory and, following Berry and Pred (1965, p. 10), we "view central place studies broadly" in order to understand the "functioning of cities as retail and service centers for surrounding areas". 
We focus upon two critical elements of central place studies that highlight the need for a second theory of external urban process: the inherent hierarchical relations and the varying scales at which they operate.

\section{$\underline{\text { Critiques of Inter-Urban Hierarchical Relations }}$}

Hierarchies are there to be climbed and therefore city hierarchies imply competitive inter-city relations. And, of course, there is a large literature on competition between cities (Lever and Turok, 1999) that derives from this thinking. But this is not the only form that inter-city relations take. For instance, for Meijers (2007, p. 248) there is cooperation between cities: he identifies "complementarity" as "a main feature of the network model". This is important because whereas central place theory only treats vertical asymmetric relations between urban places, "complementarity results in two-way flows between both different and similar-sized cities, thus emphasizing also horizontal accessibility" (p. 248). For Meijers, this argument has been used to justify the concept of polycentric urban regions; essentially the same argument has been used also to underpin the concept of a world city network where it is argued that mutuality is necessary for the operation of the network (Taylor, 2004, pp. 210-212). Complementarity, mutuality, cooperation, of course there is nothing new in such arguments: it was just such 'non-hierarchical links' that Pred (1977) illustrated so clearly in his classic study of the spaceeconomy three decades ago. The conclusion is that non-hierarchical inter-city links require an alternative theorizing to central place theory. 
It is important to note here that for all the research advances made in urban economics on intra-urban agglomeration, there has been no equivalent development in modelling inter-urban relations. However Krugman (1995, p. 93) has called upon urban economists to produce "a model to exhibit at least some central-place features" because no model of "the spatial relationship of cities to each other" is deemed to exist: thus has Christaller, and hierarchical inter-city relations, become a topic in urban economics. For instance, Fujita and Thisse's (2002) attempt to formally model inter-city relations strictly follows Krugman's lead; they overtly set out to "generate a hierarchical urban system à la Christaller" (p. 354). Although their text is primarily about urban agglomeration, in a series of steps they consider inter-city relations (pp. 115, 351-353, 354, 385-386) and are able to produce what they call a 'fuzzy' version of Christaller:

a more intricate pattern of trade in which horizontal relations are superimposed on the pyramidal structure of central place theory. (p. 385).

What they have actually derived is a complex pattern of inter-city relations 'à la Pred' - Pred (1977) is their final reference on the topic. Thus it appears that Pred's crucial findings on the space-economy are an end-product of urban economics; in this paper they are a starting point. ${ }^{4}$

This hierarchy-competition versus network-cooperation contrast goes beyond inter-city relations for it is a basic distinction in social organization in general (Powell, 1990; Thompson, 2003). The lesson of this work is that hierarchy and network are fundamentally different and should never be confused or used inter-changeably. And yet this 
is often the case in urban studies, for instance in Sassen's (1991/2001) description of the inter-city relations of global cities. The most overt example of such confusion can be found in historical studies of settlement patterns, for example in the Low Countries, where an 'urban networks' school has developed that borrowed central place theory from geography as a framework for its research (e.g. many contributions in Le réseau urbain en Belgique, 1992). This work has elicited valuable criticism from fellow historians that parallels some geographical debate. First, the idea that simple ranking of cities on one or more variables, such as population size, proves the existence of substantial hierarchical relations between cities is debunked by Blockmans (1992, pp. 246-247), and also by Bruneel (1992, pp. 95-96), but continued to be a feature of Stabel's (1997) work. This criticism harks back to Lukermann's (1966) argument that to show the existence of a hierarchy, power relations between levels must be demonstrated (Taylor, 1997). Second, Kooij (1992, pp. 514-515) and Lesger (1990, pp. 15-16) point out that central place theory can provide only a partial description of inter-city relations. In this respect, Lesger (2006, p. 184) remarks "that the spatial organization of wholesale trade has not often tempted theorists", referring to Vance (1970) as an exception. But perhaps the most important criticism from this historical debate concerns agency. Quite simply, according to Murray (2000, p. 3), writing about the spatial position of Bruges in the Low Countries, "too often this has been viewed as a simple hierarchy [...]. What we have lost sight of is the behavior of the Bruges merchants themselves [...]. The complexity of their behavior simply cannot be approximated by static or purely hierarchical models". Harreld (2004, p. 98) advocates "[p]lotting the commercial networks that individual merchants and merchant firms set up". Such social network analyses of merchants' 
contacts are found to be much more complex than simple central place hierarchies (Harreld, 2006, pp. 3-4). This complexity is made clear in Lesger's (2006, pp. 184-195) model of a "gateway system". According to Lesger (2006, pp. 261-262)

trade was organized in flexible network-like structures. This applies both to the flows of goods and to the participants. Contrary to what one might expect from research into the spatial structure of trade, the nodal points in the network system were not fixed in permanent hierarchies of staple places, with a dominant centre at the summit of the hierarchy. On the contrary, although the location of the gateways was, of course, fixed, their relative positions and importance in the hierarchy were impermanent and prone to constant change. The participants also formed parts of network-like structures, with partners, factors and subordinates in the various gateways, and a great deal of travelling to profit from the specialization and locational advantages of specific nodal points.

We adopt a similar approach to Harreld's and Lesger's below.

We are not arguing here that cities are not organised into hierarchies, but we are arguing that there is more to inter-city relations than such hierarchies. Central place theory takes reasonable care of hierarchical relations, but is deficient for understanding complex non-hierarchical relations. Unfortunately several scholars have attempted to stretch central place theory beyond its competences and this is well illustrated in debates on the hierarchical scales to be found in central place studies. 


\section{Limits to Hierarchical Scales?}

Central place theory incorporates a model of interlocking hierarchies for which no upper limit is specified. Although Christaller (1933/1966) initially limited his studies to the regional scale within Germany; in relaying his ideas to an Anglophone audience the world became the limit. Berry and Pred's (1965, p. 7) hierarchy, for instance, "culminates in a world economy, [serviced] by 'world cities"' and Mayer (1969, p. 19) invokes Hall's (1966) classic The World Cities to claim that "at the top of the hierarchy is the 'world city', whose service area for some functions may be intercontinental". But this was not really a presage for the contemporary interest in global/world cities since in practice central place thinking was limited to two main scales of analysis: rural-regional and national.

Christaller's (1933/1966) choice of study region is not without importance; Cartier (2002, p. 92) describes it as "a densely settled agricultural landscape in southern Germany". This 'rural-regional' context is common in classic treatments of central place theory: Berry's basic text (1967, chapter 1) provides an empirical introduction to the theory using rural lowan settlement patterns, and Skinner (1964, p. 3) introduces his classic historical application of the theory to China as an "analysis of rural marketing"; Corbett and Rebich (2007, p. 1) explicitly refer to his subject matter as a "rural hierarchy". Put simply, this is the spatial context in which the theory's normative assumptions are most closely matched. Nevertheless all these sources understand that there are higher scales of hierarchy: Berry (1967, pp. 22-3) refers to Minneapolis' wholesaling function for the 
upper Midwest which includes lowa; Skinner (1964, pp. 9-10) discusses problems of dealing with higher levels; and Christaller (1933/1966, p. 158) presents a whole set of 10 hierarchical levels, 8 within the region and two beyond.

Christaller's hierarchical levels are of particular interest because of their relation to political boundaries. Later studies have taken political boundaries as limits of central place hierarchies - Blockmans (1992) criticizes the research on historical 'urban networks' for precisely this error - but this is not the case with Christaller. In southern Germany, Munich is the top of the hierarchy; it is an 'L-center' of an 'L-system' of central place settlements (Christaller, 1933/1966, pp. 170-173). The surrounding cities at this same level are listed as Stuttgart, Nuremberg, Prague, Vienna, Venice and Zurich. Note that four of the six are outside Germany. In a later less well-known study, Christaller (1950) builds upon this trans-border work by postulating a spatial order of European cities that he claimed to be "hidden behind state and administrative boundaries, transport networks and population agglomerations" (p. 5, authors' translation). Dividing Europe into nine subdivisions to act as the largest level of hinterland (Figure 1), he arranges his grid to pinpoint where the leading European cities should be located (Christaller, 1950, map 2). He claims that "if Liverpool and Hamburg were major metropolises instead of London and Berlin (or Meißner), there would be no fault in the regular distribution of major metropolises" (p. 18, authors' translation). ${ }^{5}$ However, the point we wish to make about this study for the moment is that Christaller is no respecter of political boundaries. This was one aspect of his work that was not carried into its diffusion into Anglophone geography. 
The second major scale of analysis in central place thinking has been the national, encompassing 'national urban systems' with 'national urban hierarchies'. As their name suggests, these concepts were treated as bounded systems enabling further concepts such as entropy to provide new tools of measurement for development (Berry, 1961) and modernization (Gould, 1970) of states. This statecentric thinking was generally translated into spatial planning tools for national policy studies. In Bourne (1976), for example, the national urban systems of four countries - Britain, Sweden, Australia and Canada - are presented as aids for "strategies of regulation". Each country is studied as a closed system except for one comment on Swedish cities being "in direct competition with Continental cities" (p. 108). Despite this severe limitation, the urban systems school has been probably the main application of central place thinking; it ensured national planners/politicians viewed cities hierarchically and therefore in perennial competition with each other.

It has been this thinking that has been transferred to the global/world cities literature via Friedmann (1986, 1995). His world city hierarchy with London, New York and Tokyo at the top appears to be etched into globalization consciousness. This is a case of concepts from the national scale being 'up-scaled' to the global level (Taylor, 2004). Hall (2002) has attempted to convert this broad thinking into a more strict Christaller framework by extending his hierarchy to the global scale. But perhaps this is a scale too far: from the very beginning Ullman (1941, p. 856) had noted that empirically central place patterning works less well for higher levels of urban places. It may be, therefore, that the world city hierarchy is best interpreted as illustrating the limits of central place ideas for understanding city development. Certainly London, New York and Tokyo are very 
important central places, but their economic power is based upon much more than their respective central place prowess. It is time to look again at network in relation to hierarchy.

\section{Introducing two Processes: Town-ness and City-ness}

The common denominator in our misgivings about the salience of the central place process for understanding cities is the neglect of nonlocal and non-hierarchical relations. Here we are following a train of thought developed in historical urban studies by Hohenberg and Lees (1985). Whether wholesaling, long-distance trade or horizontal links in general, it appears that we need a second urban theory of external relations for understanding city development. Once again this has been recognised in early studies: Berry and Pred (1965, p. 6) state that

rather than being a general theory of cities ... It is more limited than Christaller originally thought because other principles of urbanism are needed.

These other principles are not formally spelt out although Berry (1967, pp. 108-109) subsequently did contrast theories of market origins in a framework of local surpluses (central place theory) versus "external trade", which we develop as central flow theory. At this stage of the argument this is broadly similar to Hohenberg and Lees' (1985, pp. 58-59, pp. 238-241) proposed "dual systems" for studying external urban relations: they call their 'systems' the Central Place System and the Network System (see also Lesger, 1990, pp. 15-16). 
Our contribution will not develop this systems thinking but rather we will focus on modelling the two processes.

The starting point is to name them as two distinct processes (Taylor, 2007b). The external relations that link an urban place to its hinterland we term 'town-ness'. We argue that since all urban places have hinterlands they are products of town-ness but the importance of this process will vary across urban places. Generally the larger urban places are less constituted by town-ness and more by the second urban external relations process: city-ness. This process represents inter-city relations that are broadly horizontal and beyond the hinterland. Town-ness is described by central place theory (more specifically by Christaller's marketing principle) and is modelled as urban hierarchies, whereas city-ness is described by central flow theory and is modelled as urban networks. Two key points arise from this formulation.

First, there is the important move from seeing the urban as process rather than place. Cities have been interpreted in this way by both Jacobs (1969) and Castells (1996/2001) and we extend this form of thinking to towns. The basic reason for treating towns and cities as processes rather than places is to overcome the spatial exclusivity of the latter in which an urban place is deemed either a town or a city. As processes, town-ness and city-ness can and do occur simultaneously in urban places. Every urban place, therefore, is constituted through both town-ness processes and city-ness processes. The interesting question is the balance between the two processes for any given urban example. 
Second, we need to briefly explain our particular terminology. City and town are English language terms that are sometimes used interchangeably; in dictionaries cities are commonly just defined as 'large towns'. ${ }^{6}$ Treating them as distinct processes is therefore a new conceptual departure: this paper is about arguing for the utility of this lexicon departure. In other languages there are not separate terms for city and town. In German, for instance, Stadt means both city and town although in the English translation of Christaller (1933) it is presented as 'town' (Christaller, 1966). However, even in English there are differences in the use of these terms. According to Mayer (1969, p. 7) "what Americans conceive of as a city is embraced by the British term 'Town' ... British 'town planning' has the same meaning as the American term 'city planning'". We would add that the word 'metropolitan' is commonly used by Americans for the urban place where city-ness processes dominate, and this term does have equivalents in other languages. For instance, the use of 'metropolitan' in early twentieth century sociology relates to our twoprocess argument: urban external relations were studied in two separate groups of pioneer researchers: urban-rural marketing relations (e.g. Galpin, 1923) and metropolitan dominance relations (e.g. McKenzie, 1933). In a similar manner Skinner (1964, pp. 7-9) concentrates on rural marketing through 'standard', 'intermediate' and 'central' market towns while explicitly leaving the more complex structure of the local and regional city markets outside his analyses. The early sociological division of labour and Skinner's division of subject matter both point towards our identification of two distinctive urban external processes. The use of the terms town-ness and cityness can be interpreted as both an opportunistic application of the dual urban ascription in English and a conceptual clarification of the 
confusion caused by their inherent inter-changeability in common usage.

The remainder of this paper provides a restatement of central place theory as town-ness and an introduction to central flow theory as cityness.

\section{Restating Central Place Theory as Generic Local Town-ness}

The precipitous decline of central place studies in the late twentieth century (Blotevogel, 1996) was due to a large degree to its central importance in a naïve positivist school of quantitative geography. Our rehabilitation of central place process is to argue that rather than being a theoretical source for laws of human spatial behaviour (the positivist position), it describes mechanisms generic to the social construction of towns and cities (a critical realist position). Thus we claim central place theory to be a formal description of a generic urban process. This is clearly suggested by the wide range of its applications across both time and space. There have been claims to limit the theory to specific social contexts but, when put together, these actually reinforce the generic position. For example, Skinner (1964, p. 3) asserts that his analysis of rural marketing in China has relevance for all "traditional agrarian societies", whereas Meijers (2007, p. 247) sequences central place theory as a feature of "industrial economies" before the contemporary move to service economies. A brief visit to any shopping centre (downtown) today will cast doubt on the idea that central place ideas do not have current 'post-industrial' relevance: contemporary consumer society continues

its buying spree largely in urban places. Thus we concur with Berry 
and Pred's (1965, p. 11) assessment that central place functions are "universal" in the make up of urban places (despite its positivistic suggestion); that is to say, they are generic mechanisms of what it is to be urban.

\section{The Interlocking Hierarchy Model}

Central place process can be interpreted as the local dimension in urban external relations. In the formal specification of the model this is explicitly designated as bounded hinterlands (hexagons) around each urban settlement. But note that the concept of what is 'local', and therefore particular to a central place, is variable: the scale of hinterlands increases with the level of the central place. For instance, in national urban systems research the city at the top of the hierarchy has the whole country as its hinterland for its highest-level marketing. The key characteristic about local in this context therefore, is not its intrinsic smallness but that it is bounded within a larger sphere that is non-local. It follows that the latter term is variable depending on the local it is defined by. This is a model that is premised upon multiple inside-outside definitions that describe a hierarchical space of places.

In the classic marketing principle as described by Christaller (1933/1966) as his main model, the hierarchical process is quite unusual. In most social hierarchies the relations between levels can be described by a basic tree structure showing nested hierarchical strings ensuring loyalties across levels rather than within levels. The central place process is very different from this since each central place is located on the border between two higher-level places so 
that its hinterland is divided in half when allocated to servicing at the higher level. This produces an interlocking hierarchical pattern rather than a simple linear tree ordering. It is theoretically shown to be most efficient in bringing buyers to sellers, the agents of the town-ness process. They create an inherent between-ness of central places through hierarchies that operate particularly effectively when combined with the time concept of sequenced circuits in periodic markets to provide services to buyers in poor or low population regions (Skinner, 1964, pp. 10-16). This is a model that is premised upon multiple between-ness relations that define an interlocking space of places.

In the formal derivation of this model, specific concepts are defined (e.g. range of good and market threshold) and the relations mathematized in quite complex ways. However, our basic argument is that the central place process is essentially simple in comparison with central flow theory.

\section{$\underline{\text { Town-ness as Simple Urban External Relations }}$}

Town-ness is a local affair and as such is inherently non-dynamic as an economic process. Following Jacobs (1969), economic expansion does not occur as a result of servicing a hinterland, however large. Therefore no small central place ever grew to become a metropolitan economy through external relations limited to its own hinterland. The town-hinterland relation is a relatively stable relation, not prone to rapid economic changes. In a rapidly changing economy, urbanhinterland relations will certainly change but they will never be at the cutting edge of economic development. 
The basic reason why central place processes do not create economic development is because they include no local mechanism for expanding economic activity. Urban places grow by economic expansion deriving from the introduction of 'new work' creating a more complex division of labour (Jacobs, 1969). Such dynamism will require inter-urban relations beyond servicing the local, whatever the hierarchical level. Thus economic change is something that occurs through a different process (city-ness) that does not restrict (simplify) inter-urban relations through a hierarchical structure. In contrast, town-ness is a process that inherently generates dependence through hierarchy rather than opportunity through more complete and complex inter-urban relations.

Town-ness may be inherently simple as an economic process but this does not mean that central place process is not important as the spatial organization through which society reproduces itself (distribution and consumption). This was tragically illustrated by the Chinese Communist 'Great Leap Forward' of 1958 when traditional rural marketing systems were dismantled and replaced by state institutions resulting in famine; this forced the state to reconstitute the traditional central place markets by 1961 (Skinner, 1965). In other words town-ness is a generic process that is a necessary composite of urbanized societies but there is more to urban external relations than the central place process. 


\section{Introducing Central Flow Theory as Generic Non-local City-ness}

Central flow theory is about bringing the non-local into an urban place to create a cosmopolitan mix of peoples, commodities and ideas. City-ness incorporates an inter-urban process, a network process that links together cities across different regions: this defines a broad hinterworld (Taylor, 2004), beyond the hinterland. The result is to make cities special places, unique settlements within which economic expansion occurs (Jacobs, 1969). We argue that city-ness as a generic feature of being urban differs from town-ness through its inherent complexity.

\section{$\underline{\text { City-ness as Complex Urban External Relations }}$}

Cities are dynamic and complex and this derives from the city-ness network process. According to Jacobs (1969) city networks are central to economic expansion through the mechanism of import replacement. This is how 'new work' in a city is created: local production replaces imports from other cities. This contrasts with economic growth by expanding current old work, which only increases the size of an economy but not its complexity. Adding new work makes the division of labour broader and more varied. This is expansion of economic life based upon an increasingly complex economy. Jacobs (1969) argues that such import replacement tends to occur in economic spurts and in this way can convert an 'ordinary town' into an 'extraordinary city'. In the argument developed here an urban place dominated by town-ness process may be quickly changed by enhanced city-ness process: its economy will change 
from being simple and local (hinterland-based) to being complex with important non-local-links (hinterworld-based).

Because of city-ness, larger urban places are the locus of economic expansion: 'dynamic cities' are central to economic development. In addition, because they are complex economic units they are resilient to adverse change. And because they are a network process, their relations define mutuality: all cities in a network need each other in both good times and bad. This is why cities never exist alone; they come in assemblages, ordered as networks.

Thus the spatial organization of economic development (production of commodities as goods and services) is a space of flows: a network of dynamic cities. We claim city-ness is a generic feature of all urbanized societies. It has certainly been a feature of the modern world-system; here are the dense networks of vibrant cities that have led its rise and economic expansion: northern and central Italian cities in the fifteenth and sixteenth centuries; Dutch cities in the late sixteenth and seventeenth centuries; British cities in the late eighteenth and nineteenth centuries; US, German and Japanese cities in the late nineteenth and twentieth centuries; and with East Asian cities leading world-economy expansion in the late twentieth and twenty first centuries. But city networks have been widely identified before modernity. For instance, Abu-Lughod (1989, p. 34) described eight overlapping economic 'circuits' in the thirteenth century that straddled the world from China to Western Europe: her discussion makes clear that these were city networks with transcircuit trade for mutual benefit. Hohenberg and Lees' (1985) identification of their 'Network System' operating throughout the 
whole history of 'urban Europe' remains an exemplary work for supporting our generic argument.

\section{The Interlocking Network Model}

In their 'dual systems' approach to urban external relations, Hohenberg and Lees (1985) have been able, like us, to refer to formal specification of one half of the duo, their 'central place system' (Christaller 1933/1966), but they provide no specification of the second half, the 'network system'. Although it is clear from their description of the latter (e.g. "long distance trade and a more complex division of labour" (pp. 58-59)), that they are thinking along very similar lines to us, they do not formally specify their network. Merely identifying 'nodality' rather than 'centrality' (p. 240) for distinguishing the second 'urban system' is not in itself a specification of the model. Without explicit incorporation of agents of change into the model, descriptions of city networks run the danger of reifying the city. Hence we differ from Hohenberg and Lees (1985) by formally providing a network model specification. Such a need has also been identified for the contemporary rise of urban network analyses in polycentric urban studies: Van Nuffel and Saey (2005, p. 316) complain that 'urban network' is a policy concept and not an analytical concept", implying a need for formal specification.

The specification presented here was first produced for understanding cities in contemporary globalization as a 'world city network' (Taylor, 2001; 2004), but has since been adapted to measure relations between cities on various scales (Taylor et al., 2008; 2009; Hoyler et al., 2008). We begin by describing the model 
in its original context before arguing for its generic relevance. Following Sassen (1991/2001), we interpret advanced producer services (professional, creative and financial) as a critical cutting edge sector in economic globalization. They service global capital through solving the problems of operating in a large transnational economy. These services have massively expanded in the last few decades and have contributed greatly to the new work that has created the dynamic and complex urban places that are called global or world cities. A key feature of these cities is that the import replacement mechanism has operated on a worldwide scale to produce a world city network.

City-ness is a process and therefore there have to be agents who operationalize the process: cities do not replace imports, firms in cities do. In the case of the world city network the agents are the advanced producer service firms with global clientele. To service the latter, they operate through extensive office networks in cities across all world regions. It is the amalgam of these firms' office networks that constitutes the world city network. Inter-city relations are the flows of ideas, knowledge, information, plans, instructions, personnel, etc that are made in the everyday business of carrying out advanced producer service projects (e.g. inter-jurisdictional contracts, global advertising campaigns). Thus it is that the service firms 'interlock' the cities and this can be formally specified as an interlocking network model (Taylor, 2001). Notice that this network model is unlike the usual social network. The latter typically has two levels: nodal and network. The world city network has an additional level: sub-nodal (the firms), nodal (the cities) and network (city network). And it is in the extra sub-nodal level that we locate the agents, the service firms 
that are the network makers: world cities do not make the world city network, advanced producer service firms do.

It is an important property of this model that it does not reify the city. Since firms are the agents in the process it is they who are in competition within the world markets for the various services being offered (law, accountancy, advertising, etc). This is very different from the cities themselves being in competition (as would be posited with a large-scale central place process). In fact, from the viewpoint of the agents, firms have a vested interest in all cities in their office networks being successful. Thus, instead of a global bank seeing London and Frankfurt as rival financial centres in Europe, they will have offices in both cities and will use the cities in different ways, for instance London as the platform for their global operations, Frankfurt for their expansion into central and eastern Europe (Beaverstock et al., 2001). This is the basic source of the mutuality in the world city network.

Although the interlocking network model was devised to study contemporary cities in globalization we now contend that it constitutes a generic model for city-ness, for describing city networks beyond current globalization. Vibrant, dynamic cities have always been interlocked by 'foreign' commerce - this has been what has made them cosmopolitan. Merchants, in particular, have been organised so that they have representatives in all the cities important to their business. Verbruggen (2007) makes the case for this model to be suitable for the development of a transnational city network in late medieval and early modern Europe. In fact, this process has been so strong in urban place constitution that it has been common in many historical networks for different parts of the city to be given 
over to different communities of foreign traders and producers. The point is that city networks are constituted by the interlocking of cities by commercial agents in the everyday course of their business practice - ergo, the interlocking network model is a generic central flow theory.

\section{Concluding Comment}

Like Hohenberg and Lees (1985, p. 240), and as our title states, we treat central place theory as complementary to our excursion into city networks. In our interpretation, the key difference between the two processes we identify is their respective social space formation. In central place theory centrality of location is the basic building block upon which spaces of places are formally constructed. In contrast, in central flow theory it is flows that come to centre stage as the building block generating a network; it is a space of flows that is formally constructed. In other words it is a matter of what is central, place or flow. All other differences, including the important policy implications of seeing cities in competition or cooperation, stem from these alternative spatial constructions. Of course, both frameworks include both places and flows, it is a matter of where to start the modelling which itself indicates an analytical priority: in central place theory places make flows, in central flow theory flows make places. In the world/global cities literature, this argument mirrors Allen's (1999, pp. 202-203) distinction between 'city networks' and 'networks of cities': he identifies Sassen's (1991/2001) 'global city' thesis with the former thus betraying her specific concern for 'place', whereas Castells' (1996/2001) focus is on the latter confirming 'flows' at the core of his analysis. 
We will conclude by illustrating this critical point by comparing recent findings from the interlocking network model with Christaller's (1950) European spatial structure (Figure 1). Christaller is describing a relatively simple urban space of places. A roughly equivalent urban space of flows can be created by computing the relations between the leading nine cities that dominate the European section of the world city network. Data collected in 2004 describe the world city network in terms of the office networks of 80 advanced producer service firms (Taylor and Aranya, 2008). Abstracting just the leading nine European cities from these data, the interlocking network model can be used to produce estimates of the business connections between the cities. Note that our units of interest are not cities per se, but rather city dyads. These are depicted in Figure 2. We can agree that what this model describes is a very complex European space of flows. This is just a glimpse of the complexity of central flow theory in relation to central place theory. Much more empirical work needs to be done to make sense of the "blizzard of transactions" that constitutes a world economy of "unimaginable complexity" (Thrift, 1999 , p. 272, p. 274), but it is necessary also to get our theories and concepts in proper order as a sound basis for embarking on this research journey. This paper has suggested one way forward in this respect. 


\section{References}

Abu-Lughod, J. L. (1989) Before European Hegemony: The World System A.D. 1250-1350. New York: Oxford University Press.

Allen, J. (1999) Cities of power and influence: settled formations, in:

J. Allen, D. Massey and M. Pryke (Eds.) Unsettling Cities: Movement/Settlement, pp. 181-218. London: Routledge.

Arrighi, G. (1994) The Long Twentieth Century. London: Verso.

Bassett, K. and Short, J. (1989) Development and diversity in urban geography, in: D. Gregory and R. Walford (Eds.) Horizons in Human Geography, pp. 175-193. Basingstoke: Macmillan.

Batten, D. F. (1995) Network cities: creative urban agglomerations for the 21st century, Urban Studies, 32, pp. 313-327.

Beaverstock, J. V., Hoyler, M., Pain, K. and Taylor, P. J. (2001) Comparing London and Frankfurt as World Cities: A Relational Study of Contemporary Urban Change. London: Anglo-German Foundation for the Study of Industrial Society. 
Berry, B. J. L. (1961) City size distributions and economic development, Economic Development and Cultural Change, 9, pp. 573-588.

Berry, B. J. L. (1967) Geography of Market Centers and Retail Distribution. Englewood Cliffs, NJ: Prentice-Hall.

Berry, B. J. L. and Pred, A. (1965) Central Place Studies: A Bibliography of Theory and Applications. Philadelphia: Regional Science Research Institute.

Blockmans, W. (1992) Des systèmes urbains: pourquoi? In: Le réseau urbain en Belgique dans une perspective historique (13501850), pp. 243-248. Brussels: Crédit Communal.

Blotevogel, H. H. (1996) Zentrale Orte: zur Karriere und Krise eines Konzepts in Geographie und Raumplanung, Erdkunde, 50, pp. 9-25.

Bobek, H. (1927) Grundfragen der Stadtgeographie, Geographischer Anzeiger, 28, pp. 213-224. 
Bourne, L. S. (1976) Urban Systems: Strategies for Regulation. Oxford: Clarendon Press.

Bourne, L. S. and Simmons, J. W. (Eds.) (1978) Systems of Cities. New York: Oxford University Press.

Bruneel, C. (1992) Hiérarchie et réseaux brabançons: les vues nouvelles au banc d'essai, in: Le réseau urbain en Belgique dans une perspective historique (1350-1850), pp. 81-109. Brussels: Crédit Communal.

Camagni, R. and Salone, C. (1993) Network urban structures in northern Italy: elements for a theoretical framework, Urban Studies, 30, pp. 1053-1064.

Cartier, C. (2002) Origins and evolution of a geographical idea: the macroregion in China, Modern China, 28, pp. 79-142.

Castells, M. (1996/2001) The Rise of the Network Society. Oxford: Blackwell. 
Christaller, W. (1933/1966) Die zentralen Orte in Süddeutschland. Jena: Gustav Fischer Verlag; translated by C. W. Baskin as Central Places in Southern Germany. Englewood Cliffs, NJ: Prentice-Hall.

Christaller, W. (1950) Das Grundgerüst der räumlichen Ordnung in Europa: Die Systeme der europäischen zentralen Orte. Frankfurter Geographische Hefte, 24, 1. Frankfurt am Main: Kramer.

Corbett, J. and Rebich, S. (2007) G. William Skinner: Marketing in rural China, 1964-65, Back to Classics (www.csiss.org/classics/content/96).

Dale, B. and Sjøholt, P. (2007) The changing structure of the central place system in Trøndelag, Norway, over the past 40 years - viewed in the light of old and recent theories and trends, Geografiska Annaler, 89B (S1), pp. 13-30.

Davies, W. K. D. (1998) Urban systems research: unfulfilled promises? Canadian Journal of Regional Science, 11, pp. 349-356.

Friedmann, J. (1986) The world city hypothesis, Development and Change, 17, pp. 69-83. 
Friedmann, J. (1995) Where we stand: a decade of world city research, in: P.J. Taylor and P.L. Knox (Eds.) World Cities in a World-System, pp. 21-47. Cambridge: Cambridge University Press.

Fujita, M. and Thisse, J.-F. (2002) Economics of Agglomeration: Cities, Industrial Location, and Regional Growth. Cambridge: Cambridge University Press.

Galpin, C. J. (1923) Rural Life. New York: The Century Co.

Glaeser, E.L., Kallal, H.D., Scheinkman, J.A. and Shleifer, A (1992) Growth in cities, The Journal of Political Economy, 100, pp. 1126-52

Gould, P. (1970) Tanzania 1920-63: the spatial impress of the modernization process, World Politics, 22, pp. 149-170.

Hall, P. (1966) The World Cities. London: Heinemann.

Hall, P. (2002) Christaller for a global age: redrawing the urban hierarchy, in: A. Mayr, M. Meurer and J. Vogt (Eds.) Stadt und 
Region: Dynamik von Lebenswelten, pp. 110-128. Leipzig: Deutsche Gesellschaft für Geographie.

Harreld, D. J. (2004) High Germans in the Low Countries: German Merchants and Commerce in Golden Age Antwerp. Leiden: Brill.

Harreld, D. J. (2006) Merchants and international trade networks in the sixteenth century, Paper presented at the XIV International Economic History Congress, Helsinki, 21-25 August 2006 (www.helsinki.fi/iehc2006/papers3/Harreld.pdf).

Harris, C. D. and Ullman, E. L. (1945) The nature of cities, Annals of the American Academy of Political and Social Science, 242, pp. 717.

Hohenberg, P. M. and Lees, L. H. (1985) The Making of Urban Europe, 1000-1950. Cambridge, MA: Harvard University Press.

Hoyler, M., Freytag, T. and Mager, C. (2008) Connecting RhineMain: the production of multi-scalar polycentricities through knowledge-intensive business services, Regional Studies, 42, pp. 1095-1111. 
Jacobs, J. (1969) The Economy of Cities. New York: Vintage.

Knaap, G. A. van der (2002) Stedelijke Bewegingsruimte: over Veranderingen in Stad en Land. The Hague: Sdu Uitgevers.

Kooij, P. (1992) Het stedensysteem in België. Observaties van 'over de grens', in: Le réseau urbain en Belgique dans une perspective historique (1350-1850), pp. 509-520. Brussels: Crédit Communal.

Krugman, P. (1995) Development, Geography, and Economic Theory. Cambridge, MA: MIT Press.

Le réseau urbain en Belgique dans une perspective historique (13501850) (1992). Brussels: Crédit Communal.

Lesger, C. (1990) Hoorn als stedelijk knooppunt. Stedensystemen tijdens de late middeleeuwen en vroegmoderne tijd. Hilversum: Verloren.

Lesger, C. (2006) The Rise of the Amsterdam Market and Information Exchange: Merchants, Commercial Expansion and 
Change in the Spatial Economy of the Low Countries c. 1550-1630. Aldershot: Ashgate.

Lever, W. F. and Turok, I. (1999) Competitive cities: introduction to the review, Urban Studies, 36, pp. 791-793.

Lukermann, F. (1966) Empirical expressions of nodality and hierarchy in a circulation manifold, East Lakes Geographer, 2, pp. $17-44$.

Mayer, H. M. (1969) Cities and urban geography, Journal of Geography, 27, pp. 6-19.

McKenzie, R. D. (1933) The Metropolitan Community. New York: McGraw-Hill.

Meijers, E. (2007) From central place to network model: theory and evidence of a paradigm change, Tijdschrift voor Economische en Sociale Geografie, 98, pp. 245-259.

Murray, J. (2000) Of nodes and networks: Bruges and the infrastructure of trade in fourteenth-century Europe, in: P. Stabel, B. 
Blondé and A. Greve (Eds.) International Trade in the Low Countries (14th - 16th Centuries), pp. 1-14. Leuven: Garant.

Nuffel, N. van and Saey, P. (2004) Commuting, hierarchy and networking: the case of Flanders, Tijdschrift voor Economische en Sociale Geografie, 96, pp. 313-327.

Nuffel, N. van and Saey, P. (2006) Beyond Christaller: regionalisation of residential markets - the example of North Belgium, Die Erde, 137, pp. 75-99.

Parr, J. B. (2002) The location of economic activity: central place theory and the wider urban system, in: P. McCann (Ed.) Industrial Location Economics, pp. 32-82. Cheltenham: Edward Elgar.

Powell, W. W. (1990) Neither markets nor hierarchy: network forms of organization, Research in Organizational Behaviour, 12, pp. 295336.

Pred, A. (1977) City-Systems in Advanced Economies. London: Hutchinson. 
Sassen, S. (1991/2001) The Global City. Princeton, NJ: Princeton University Press.

Skinner, G.W. (1964) Marketing and social structure in rural China, Part I, Journal of Asian Studies, 24, pp. 3-43.

Skinner, G. W. (1965) Marketing and social structure in rural China, Part III, Journal of Asian Studies, 24, pp. 363-399.

Stabel, P. (1997) Dwarfs among Giants: The Flemish Urban Network in the Late Middle Ages. Leuven: Garant.

Taylor, P. J. (1997) Hierarchical tendencies amongst world cities: a global research proposal, Cities, 14, pp. 323-332.

Taylor, P. J. (2001) Specification of the world city network, Geographical Analysis, 33, pp. 181-194.

Taylor, P. J. (2004) World City Network: A Global Urban Analysis. London: Routledge. 
Taylor, P. J. (2007a) Space and sustainability: an exploratory essay on the production of social spaces through city-work, Geographical Journal, 173, pp. 197-206.

Taylor, P. J. (2007b) Cities within spaces of flows: theses for a materialist understanding of the external relations of cities, in: P. J. Taylor, B. Derudder, P. Saey and F. Witlox (Eds.) Cities in Globalization: Practices, Policies and Theories, pp. 287-297. London: Routledge.

Taylor, P.J. (2009) Urban economics in thrall to Christaller: a misguided search for city hierarchies in external urban relations, Environment and Planning A, 41 (11), pp. 2550-2555.

Taylor, P. J. and Aranya, R. (2008) A global 'urban roller coaster'? Connectivity changes in the world city network, 2000-2004', Regional Studies, 42, pp. 1-16.

Taylor, P. J., Evans, D. and Pain, K. (2008) Application of the interlocking network model to mega-city regions: measuring polycentricity within and beyond city-regions, Regional Studies, 42, pp. 1079-1093. 
Taylor, P. J., Evans, D., Hoyler, M., Derudder, B. and Pain, K. (2009) The UK space economy as practised by advanced producer service firms: identifying two distinctive polycentric city-regional processes in contemporary Britain, International Journal of Urban and Regional Research, 33 (3), pp. 700-718.

Thompson, G. F. (2003) Between Hierarchies and Markets: The Logic and Limits of Network Forms of Organization. Oxford: Oxford University Press.

Thrift, N. (1999) Cities and economic change: global governance? In: J. Allen, D. Massey and M. Pryke (Eds.) Unsettling Cities: Movement/Settlement, pp. 271-308. London: Routledge.

Ullman, E. L. (1941) A theory of location for cities, American Journal of Sociology, 46, pp. 853-864.

Vance, J. E. (1970) The Merchant's World: The Geography of Wholesaling. Englewood Cliffs, NJ: Prentice-Hall.

Verbruggen, R. (2007) The world city network in Europe between 1250 and 1640: from Christaller to Braudel. Paper presented at the 
First International Conference of Young Urban Researchers (FICYUrb), ISCTE, Lisbon, 11-12 June 2007 (http://conferencias.iscte.pt/viewabstract.php? $\mathrm{id}=138 \& \mathrm{cf}=3$ ). 
Figures

Figure 1. Christaller's European spatial structure. Source: Christaller (1950, extract from map 1).

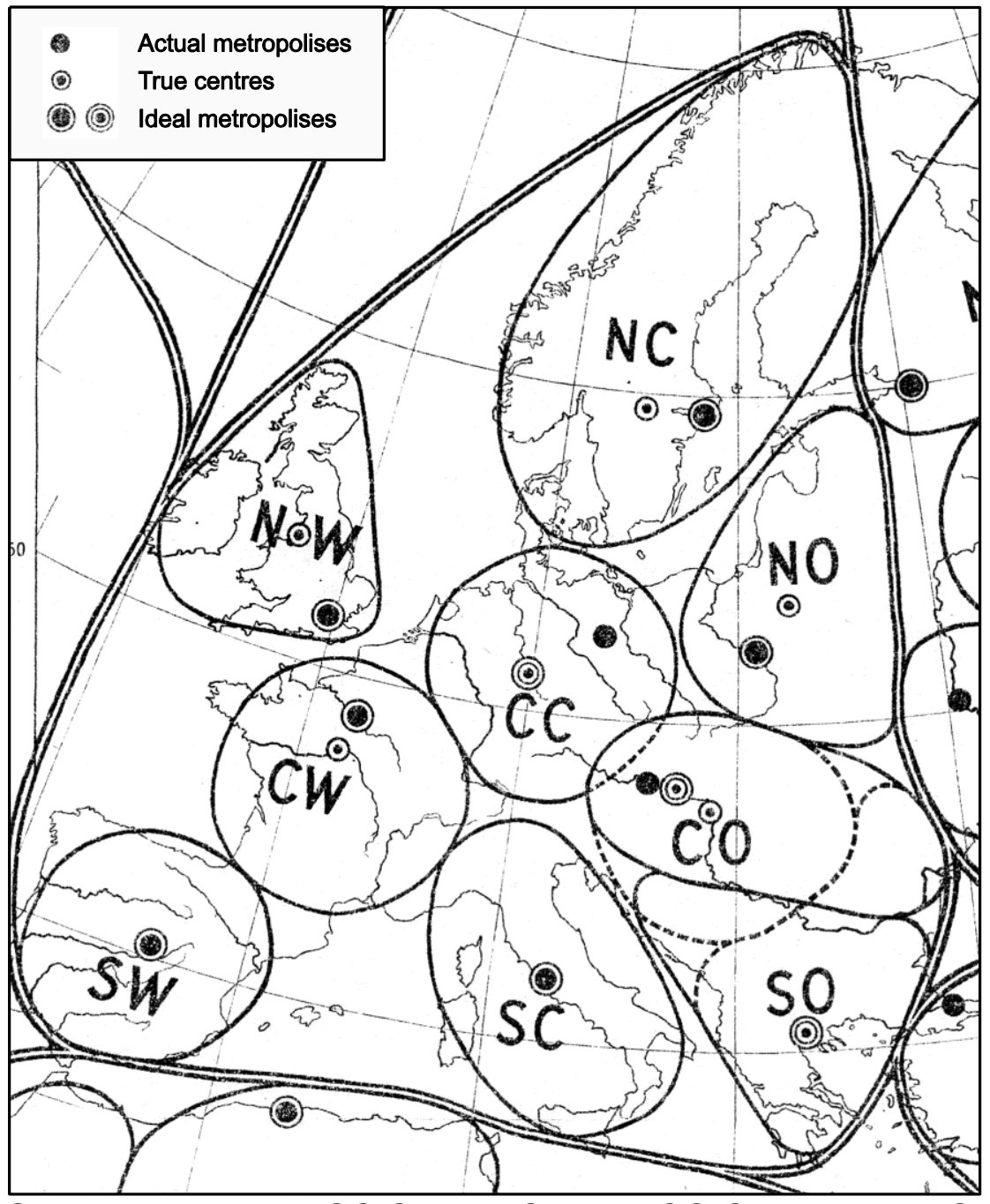

Subdivision codes: CC Central-Central, CO Central-East, CW

Central-West, NC North-Central, NO North-East, NW North-West,

SC South-Central, SO South-East, SW South-West 
Figure 2. Inter-city links between nine European cities as practised by advanced producer services.

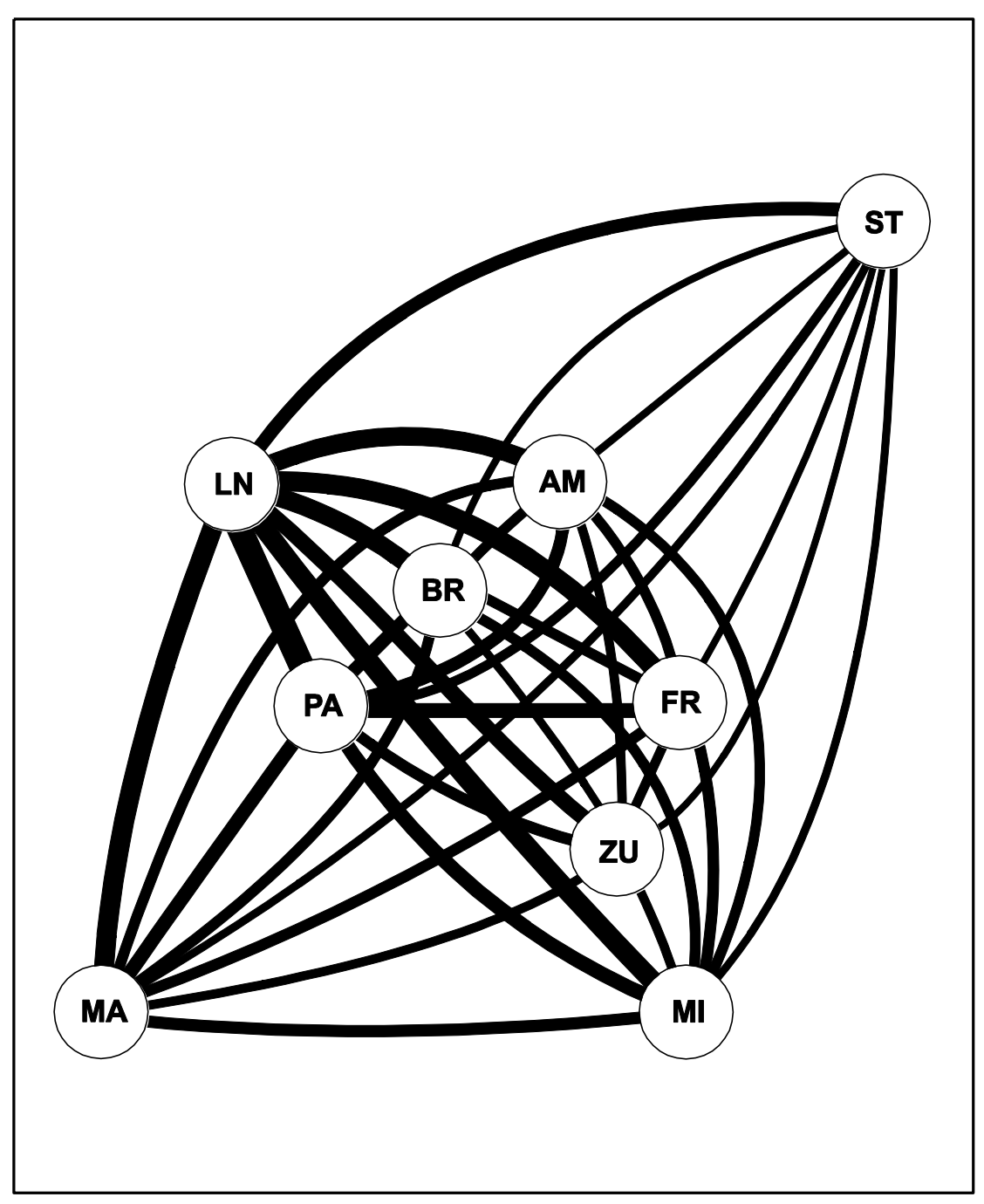

City codes: AM Amsterdam, BR Brussels, FR Frankfurt, LN London, MA Madrid, MI Milan, PA Paris, ST Stockholm, ZU Zurich 
${ }^{1}$ Research concern for inter-urban relations has been intermittent in modern geographical scholarship. Until very recently, research on external relations of towns and cities was severely neglected in urban geography; for instance, Bassett and Short's (1989) review of the sub-discipline featured only internal urban relations. This situation was criticised by Taylor (2004, pp. 1-3) as only dealing with half 'the nature of cities'. More than 70 years earlier Bobek (1927) expressed a similar criticism of geographers being "concerned ... largely with the internal geographies of cities ... in contrast to the problem of location and support of cities" (Ullman, 1941, p. 853). The response to this deficit was the growth of interest in central place theory and ultimately the development of the national urban systems school (Bourne and Simmons, 1978); in recent years urban external relations have returned to the Geography research agenda largely via the world/global city literature. In the former case the new relational thinking was built upon Christaller's (1933/1966) central place theory, which Ullman (1941; Harris and Ullman, 1945) was instrumental in introducing into Anglophone geography. In this paper we suggest that the current urban relational thinking requires a similar new conceptual grounding: we offer what we shall term 'central flow theory' as a candidate for this role.

${ }^{2}$ Krugman (1995, p. 38) famously refers to central place theory as part of the location theory he calls 'Geometric geometry' and criticises it as "a sort of schematic, a way to organize your thoughts and your data about urban systems, rather than an economic model" (p. 40). Despite Krugman's dismissal, our claim here is that, in any case, this specific way of organizing thoughts on urban systems 
percolated into economic modelling as a hierarchical urban presumption.

${ }^{3}$ See also Van Nuffel and Saey (2006, p. 81), who argue that "the development of the network society has eroded the nested hierarchy [of residential spaces], and, ipso facto, central place theory, which was designed to explain the existence of this hierarchy [...] has been rendered outdated as a possible explanation of the present-day tendencies in the structuring of residential space."

4 This interpretation of the study of inter-city relations in urban economics is presented in more detail in Taylor (2009).

${ }^{5}$ Christaller (1950) identifies and contrasts existing leading cities with the 'true' centres of his nine continental subdivisions and 'ideal locations' ("Wunschbild-Metropolen"). The Hohe Meißner, a mountain near Kassel in north-east Hesse, for example, is identified as the "true centre of the CC-system" (p. 17).

${ }^{6}$ Cities are also formally defined in terms of state designation or cathedral foundation but we are not concerned with administrative definitions here. 